\title{
Prerequisites for the Formation of the Anti-Corruption Security Theory in the Russian Federation
}

\author{
Irina A. Damm* \\ Siberian Federal University \\ Krasnoyarsk, Russian Federation
}

Received 17.08.2021, received in revised form 30.08.2021, accepted 14.09.2021

\begin{abstract}
Security is one of the basic needs of the individual, society and the state, as well as an integral condition for their development. Corruption is among the threats to the national security of the Russian Federation, as it follows from the National Security Strategy approved by Presidential Decree No. 683 of 31.12.2015. The significant efforts made by the state since the mid-2000s to form and improve social, legal and organizational mechanisms for combating corruption consistently lead to positive results. At the same time, we have to state that corruption continues to cause irreparable harm to public relations, creates an atmosphere of social tension in society. It is no coincidence that the new National Security Strategy, approved by Presidential Decree No. 400 of 02.07 .2021 , emphasizes the need of society to strengthen the fight against corruption. The high rates of development of anti-corruption legislation, as well as the institutionalization of anti-corruption structures, have led to the formation of natural intra-system contradictions that hinder the further sustainable development of anti-corruption activities. The emerging trends of stagnation of the anti-corruption system actualize the search for qualitatively new fundamental scientific developments that allow us to reach a new level of intersectoral scientific understanding and development of anti-corruption mechanisms. The current stage of the development of scientific knowledge about the phenomena of corruption and security, as well as the relevant anti-corruption and security systems, allows us to identify sufficient prerequisites for the beginning of the development of the theory of anti-corruption security, which contains methodological approaches to ensuring personal, state and global anti-corruption security.
\end{abstract}

Keywords: corruption, security, anti-corruption security, anti-corruption security measures, prevention of corruption, corruption threats, corruption risks, corruption crime.

Research area: law.

Citation: Damm, I.A., (2021). Prerequisites for the formation of the anti-corruption security theory in the Russian Federation. J. Sib. Fed. Univ. Humanit. soc. sci., 14(11), 1690-1709. DOI: 10.17516/1997$1370-0850$

(C) Siberian Federal University. All rights reserved

* Corresponding author E-mail address: idamm@yandex.ru 


\author{
И.А.Дамм \\ Сибирский федеральный университет \\ Российская Федераиия, Красноярск
}

\begin{abstract}
Аннотация. Безопасность выступает одной из базовых потребностей личности, общества и государства, а также неотъемлемым условием их развития. К числу угроз национальной безопасности Российской Федерации отнесена коррупция, как это следовало из Стратегии национальной безопасности, утвержденной Указом Президента РФ от 31.12.2015 № 683. Предпринимаемые со стороны государства с середины 2000-х годов значительные усилия по формированию и совершенствованию социальных, правовых и организационных механизмов противодействия коррупции последовательно приводят к положительным результатам. Вместе с тем приходится констатировать, что коррупция продолжает причинять невосполнимый вред общественным отношениям, создает в обществе атмосферу социальной напряженности. Неслучайно в новой Стратегии национальной безопасности, утвержденной Указом Президента РФ от 02.07.2021 № 400, подчеркивается потребность общества в усилении борьбы с коррупцией. Высокие темпы развития законодательства о противодействии коррупции, а также институционализации антикоррупционных структур привели к формированию закономерных внутрисистемных противоречий, препятствующих дальнейшему устойчивому развитию антикоррупционной деятельности. Намечающиеся тенденции стагнации системы противодействия коррупции актуализируют поиск качественно новых фундаментальных научных разработок, позволяющих выйти на новый уровень межотраслевого научного осмысления и развития антикоррупционных механизмов. Современный этап развития научных знаний о феноменах коррупции и безопасности, а также соответствующих систем противодействия коррупции и обеспечения безопасности позволяет выявить достаточные предпосылки для начала разработки теории антикоррупционной безопасности, содержащей методологические подходы к обеспечению личной, государственной и глобальной антикоррупционной безопасности.
\end{abstract}

Ключевые слова: коррупция, безопасность, антикоррупционная безопасность, антикоррупционные меры безопасности, противодействие коррупции, коррупционные угрозы, коррупционные риски, коррупционная преступность.

Научная специальность: 12.00 .00 - юридические науки.

\section{Введение в проблему исследования}

Коррупция как деструктивное социальное явление издревле сопровождает общество в различных сферах его жизнедеятельности. Потребность различных обществ и государств в защите от коррупционных посягательств обусловила появление на международном уровне базовых документов: Конвенции ООН против коррупции, европейских конвенций об уголовной и гражданско-правовой ответственности за коррупцию и др.

В преамбуле Конвенции ООН против коррупции отмечается, что коррупция уже 
не представляет собой локальную проблему, а превратилась в транснациональное явление, которое затрагивает общество и экономику всех стран. В свою очередь, для эффективного предупреждения коррупции и борьбы с ней необходим всеобъемлющий и многодисциплинарный подход. Каждому государству - участнику указанной Конвенции рекомендовано разрабатывать и осуществлять эффективную и скоординированную политику противодействия коррупции (п. 1 ст. 5), а также стремиться устанавливать и поощрять эффективные виды практики, направленные на предупреждение коррупции (п. 2 ст. 5).

В Российской Федерации обеспечение антикоррупционной деятельности осуществляется как на теоретическом, так и на практическом уровне.

Научный интерес к вопросам предупреждения коррупции начал поступательно развиваться после распада СССР и активизировался в связи с принятием пакета антикоррупционных нормативных правовых актов, ядром которых стал Федеральный закон от 25.12.2008 № 273-Ф3 «О противодействии коррупции», закрепивший правовые и организационные основы противодействия коррупции. Положения названного закона детализируются в других федеральных законах, а также многочисленных подзаконных нормативных актах. В свою очередь, уполномоченные органы регулярно разрабатывают методические рекомендации по актуальным вопросам практики правоприменения.

Значимость и основные направления антикоррупционной деятельности раскрываются в таких регулярно обновляемых социально-политических документах, как Стратегия национальной безопасности и Национальный план противодействия коррупции.

Таким образом, в Российской Федерации осуществляется активная антикоррупционная практическая работа, во многом опережающая соответствующие научнотеоретические разработки. Практикоориентированный крен в развитии системы обеспечения противодействия коррупции, с одной стороны, позволил в максимально короткие сроки создать правовую и организационную основу предупреждения коррупции. С другой стороны, привел к неизбежному формированию внутрисистемных правовых, институциональных и иных противоречий, препятствующих прогрессивному развитию системы противодействия коррупции.

\section{Концептологические основания \\ исследования}

Высокая степень общественной опасности коррупции как сложного социальноправового явления, способного причинить невосполнимый вред общественным отношениям, обусловила необходимость познания ее системно-структурных характеристик, а также выработки адекватных мер предупредительного воздействия, направленных на своевременное выявление и предупреждение коррупционных рисков.

В исследование различных аспектов коррупции вовлечены различные науки гуманитарного цикла. Регулятивные возможности права предопределили интерес представителей юриспруденции к исследованию коррупции как социально-правового феномена и в особенности к ее предупреждению. Значимый вклад в формирование фундаментальных научных правовых знаний о коррупции и о противодействии ей внесли научные труды В.В. Астанина, И.И. Бикеева, Б.В. Волженкина, С. А. Воронцова, Ю. П. Гармаева, Л. Д. Гаухмана, Г.Н. Горшенкова, А.И. Долговой, Э. А. Иванова, С.К. Илия, П. А. Кабанова, М.П. Клейменова, Н. А. Лопашенко, В.В. Лунеева, С. В. Максимова, С. А. Маркунцова, И.М. Мацкевича, А.Ф. Ноздрачева, В.А. Номоконова, А. Л. Репецкой, Э.В. Талапиной, Ю.В. Трунцевского, Т. Я. Хабриевой, А. М. Цирина, С. Е. Чаннова, Н. В. Щедрина, В.Е. Эминова, П. С. Яни и др.

Результатом активных научных изысканий стало формирование основных подходов к пониманию коррупции, выявление ее основных форм и видов, определение ключевых детерминант, а также формиро- 
вание теоретических основ предупреждения.

В свою очередь, безопасность выступает базовой потребностью человека, общества и государства в защите от различных угроз и опасностей, в связи с чем познание феномена безопасности в науке осуществляется не менее активно. Разнообразным аспектам рассматриваемой категории посвятили свои работы представители различных отраслей гуманитарного научного знания: В.А. Акимов, М.М. Бабаев, А.Н. Быков, А.Ф. Галузин, Г. Г. Горшенков, А.А. Иванова, С.М. Иншаков, М.П. Клейменов, Ю.Н. Климова, В.В. Колесников, Г.Г. Кондратенко, Ю.В. Латов, С.Я. Лебедев, В.А. Номоконов, Д.А. Панарин, А.В. Паршков, О.А. Петрянина, В.А. Плешаков, Е.В. Позднякова, А.В. Полукаров, Е.Н. Рахманова, Н.Н. Рыбалкин, А.П. Скиба, А. А. Тер-Акопов, А. Д. Урсул, Д. А. Шестаков, С.Н. Шишкарев, Н.В. Щедрин, В.И. Ярочкин и др.

Глубинная смысловая взаимосвязь коррупции как угрозы по своему содержанию и безопасности как состояния защищенности от угроз привела к появлению в научнопрактическом лексиконе термина «антикоррупционная безопасность». Вместе с тем научное познание понятия, содержания антикоррупционной безопасности, типов и видов объектов антикоррупционной охраны, внутренних и внешних угроз и источников коррупционной опасности, а также характеристик системы обеспечения антикоррупционной безопасности находится на начальной стадии развития.

\section{Постановка проблемы}

Коррупция представляет собой глобальную проблему, создающую угрозу устойчивому развитию не только отдельных государств, но и человечества. В ретроспективе появление коррупции связывается с оформлением управленческих структур еще в первобытном обществе, а в перспективе ее существование возможно в системах глобального управления человечеством.

Коррупция как многоаспектная категория не только выступает разноуровневой угрозой безопасности, но и является отражением психологии человека. Признание негативности коррупции в обществе далеко не всегда сдерживает отдельных его представителей от совершения коррупционных деяний, когда возможность личного обогащения, пусть даже и рискованного, становится реальной. Многоликость коррупции и ее исключительная приспособительность существенно осложняют поиск своевременных и адекватных мер противодействия.

Устойчивое развитие российского общества и государства напрямую зависит от эффективности государственной антикоррупционной политики. На современном этапе коррупция не только угрожает развитию социально значимых систем управления государством (образование, здравоохранение и др.), но и стала средством умышленного манипулирования общественным сознанием (Kleimenov \& Kleimenov, 2017), осуществляемым с целью дискредитации управляющих структур и повышения в государстве социальной напряженности.

В масштабах исторического развития Российской Федерации удалось в короткое время сформировать правовые и организационные основы противодействия коррупции. В практическую работу внедрены разнообразные по содержанию и интенсивности механизмы антикоррупционной деятельности как в сфере государственного управления, так и в частном секторе. Закреплены антикоррупционные стандарты деятельности, позволяющие выявлять и предотвращать коррупциогенные ситуации, осуществлять антикоррупционную экспертизу нормативных правовых актов и их проектов и пр. Созданы необходимые предпосылки для обеспечения информационной, процедурной и партисипативной открытости государственного и муниципального управления. Установлены антикоррупционные запреты, обязанности и ограничения для служащих публичной сферы. Реализуются мероприятия по антикоррупционному просвещению и антикоррупционному образованию различных социальных групп. 
Изучение содержания и практики применения антикоррупционных мер, закрепленных в отечественном законодательстве, позволяет сделать вывод о том, что потенциал развития сложившейся системы противодействия коррупции Российской Федерации практически исчерпан. В свою очередь, потребность общества и государства в усилении антикоррупционной деятельности представляется очевидной. Коррупция продолжает причинять невосполнимый вред общественным отношениям, несмотря на прилагаемые усилия и наблюдаемые от них некоторые положительные эффекты.

Преодоление намечающейся стагнации развития антикоррупционной деятельности требует поиска качественно новых межотраслевых научных подходов, позволяющих в условиях ограниченности ресурсов повысить эффективность реализуемых практических антикоррупционных мероприятий. Основой для фундаментальных изменений в данной области может стать научная разработка межотраслевой теории антикоррупционной безопасности.

\section{Обсуждение}

Научное развитие как непрерывный процесс изменений сопровождается совершенствованием или опровержением уже сложившихся теорий, выдвижением новых. В свою очередь, формирование новой научной теории предполагает наличие достаточных теоретических и эмпирических предпосылок. При этом приращение научного знания может быть детерминировано социально-политическим запросом на развитие конкретной сферы общественных отношений.

В первой, ранее действовавшей Стратегии национальной безопасности, утвержденной Указом Президента РФ от 31.12.2015 № 683, коррупция отнесена к числу основных угроз государственной и общественной безопасности наравне с такими деструктивными явлениями, как терроризм, экстремизм, деятельность преступных организаций и др. (п. 43). В Стратегии подчеркивалось, что особое внимание должно уделяться искоренению причин и условий, порождающих коррупцию, которая является препятствием устойчивому развитию Российской Федерации и реализации стратегических национальных приоритетов.

В новой Стратегии национальной безопасности, утвержденной Указом Президента РФ от 02.07.2021 № 400, отмечается потребность общества в усилении борьбы с коррупцией (п. 45), а предупреждение и пресечение преступлений коррупционной направленности отнесены к числу приоритетных задач государственной политики (пп. 13 п. 47).

Сказанное свидетельствует о том, что в современном российском обществе и государстве сформировался консолидированный запрос на поиск качественно новых фундаментальных подходов в теоретическом обосновании и практической организации антикоррупционной деятельности.

Активное формирование правовых и организационных основ профилактики и борьбы с коррупцией обусловило мощный рывок в построении и содержательном наполнении практических аспектов системы противодействия. Бурное развитие законодательства о противодействии коррупции, сопровождающееся непрерывными изменениями, привело к появлению внутрисистемных противоречий, препятствующих эффективной практике применения. В качестве примера можно привести институт конфликта интересов. Несмотря на унификацию терминологического аппарата в Федеральных законах «О противодействии коррупции», «О государственной гражданской службе», «О муниципальной службе», в ряде отраслевых законов сохранены иные определения (например, Закон РФ от 26.06.1992 № 3132-1 «О статусе судей в Российской Федерации», Федеральный закон от 12.01.1996 № 7-Ф3 «О некоммерческих организациях», Федеральный закон от 29.12.2012 № 273-Ф3 «Об образовании в Российской Федерации» и др.). Отсутствует единообразие и в организационных аспектах выявления, предупреждения и урегулирования конфликта интересов. 
В специальной литературе, а также в рамках научно-практического дискурса все чаще звучат предложения о необходимости систематизации используемых в настоящий момент разнородных механизмов противодействия коррупции, а также активизации поиска новых научно обоснованных моделей организации и содержательного наполнения антикоррупционной деятельности (Astanin, 2012; Nomokonov, 2016; Tsirin, 2016; Bratanovskii \& Zelenov, 2017; Khabrieva \& Chernogor, 2017; Zhubrin \& Ilii, 2017; Kabanov, 2018; Kleimenov, 2018a; Kozlov, 2020; Mikhailov, 2021 et al.).

Основой для смены парадигмы сложившейся системы противодействия коррупции и выхода на качественно новый уровень теоретического осмысления антикоррупционной деятельности может стать разработка межотраслевой теории антикоррупционной безопасности.

Предпосылками формирования теории антикоррупционной безопасности выступают накопленный массив межотраслевых теоретических знаний о феноменах коррупции и безопасности, практический опыт обеспечения безопасности и противодействия коррупции, а также обозначенный выше социально-политической запрос на усиление антикоррупционной деятельности государства. Потребности общества и государства в повышении эффективности антикоррупционной политики актуализируют необходимость поиска новых теоретико-методологических подходов.

Антикоррупционная теоретическая реальность в современной отечественной науке познается непрерывно. С развитием научных представлений о феномене коррупции в орбиту ее исследования вовлекается все большее количество наук, что обуславливает междисциплинарность формируемого научного знания. Различные аспекты коррупции и ее проявлений стали объектом научного познания таких наук, как философия (Alakshina, 2005; Tokarev, 2011; Izotov, 2012; Gorbova, 2016; Kondratenko, 2016 et al.), социология (Akhmetova, 2006; Alekseev, 2008; Leonteva, 2010; Kharitonova, 2013; Shedii, 2014 et al.), политология
(Bush, 2006; Tereshchenko, 2010; Bogunov, 2012; Prokuratov, 2015; Sukhanov 2015 et al.), экономика (Makarov, 2008; Iukhachev, 2010; Gribkov, 2012; Dronov, 2013; Naumov, 2014 et al.), психология (Budagov, 2012; Pechenkin, 2012; Kiselev, 2016; Pshenichniuk, 2017; Sundukova, 2020 et al.), педагогика (Khamdeev, 2014; Rybalkin, 2015; Sharapova, 2017; Sergeeva, 2018; Solovev, 2020 et al.), история (Muzalevskaia, 2006; Belov, 2008; Markosian, 2010; Kuligin, 2012; Sakharov, 2013 et al.), культурология (Siuzeva, 2013) и, конечно, юриспруденция (Kliukovskaia, 2004; Aleksandrov, 2005; Shishkarev, 2006; Kurakin, 2008; Astanin, 2009; Artemev, 2014; Aleksandrova, 2016; Polukarov, 2020; Sheverdiaev, 2020 et al.), которые изучают особенности коррупции исходя из специфики своего предмета и метода.

В массиве научных исследований коррупции и способов ее предупреждения преобладают работы представителей юриспруденции, что обусловлено регулятивными и охранительными возможностями права, воплощающего необходимые меры безопасности в нормативные предписания. Следует отметить, что научный каркас правовых теоретических исследований коррупции базируется преимущественно на достижениях наук уголовно-правового цикла. Активное участие представителей названных наук в исследовании коррупции и проблем ее противодействия обусловлено необходимостью обеспечения своевременной и адекватной реакции на угрожающие масштабы распространения коррупционных преступлений, обладающих самой высокой степенью общественной опасности в массиве коррупционных проявлений.

Значимой теоретической предпосылкой формирования нового научного знания выступает наличие базового понятийнокатегориального аппарата. В отечественной правовой науке такой аппарат активно формируется и раскрывает содержание ключевых категорий: «коррупция» (Damm, 2003; Kudashkin \& Kozlov, 2010; Belskii, 2012; Khabrieva, 2012; Shchedrin, 2014 et al.), «коррупционное правонарушение» (Bratanovskii \& Zelenov, 2011; Zyrianova, 2014; Ilii, 2015; 
Poliakov, 2015; Spektor, 2015 et al.), «коррупционное преступление» (Egorova, 2013; Skliarov, 2015; Damm, 2020; Sorochkin, 2020; Markuntsov, 2021 et al.), «коррупционные риски» (Abramova, 2012; Pomazuev, 2016; Matskevich, Antonian \& Aminov, 2017; Kabanov, 2019; Tsirin, Truntsevskii \& Sevalnev, 2019 et al.), «личность коррупционного преступника» (Goncharenko, 2008; Kabanov, 2014; Storchilova, 2017; Zhubrin et al., 2017; Kapinus, 2018 et al.), «противодействие коррупции» (Nomokonov, 2013; Gorshenkov, 2014; Vorontsov, 2015b; Damm, 2018b; Kleimenov \& Kharitonov, 2018 et al.), «антикоррупционная политика» (Astanin, 2012 et al.), «антикоррупционное просвещение» (Kabanov, 2015; Khairutdinova, 2015; Vorontsov, 2015a; Damm, 2018a; Bikeev \& Kabanov, 2019 et al.), «антикоррупционная экспертиза» (Talapina, 2007; Khabrieva, 2009; Korobkin, 2012; Rossinskaia \& Galiashin, 2012; Astanin, 2016 et al.) и др.

Современные научные знания о коррупции начинают приобретать системноструктурные характеристики. В системе научного знания можно выделить два базовых элемента: знания о феномене коррупции, а также знания о способах ее предупреждения. В свою очередь, осуществляется познание как общетеоретических аспектов коррупции, так и ее отраслевых проявлений в сфере государственного и муниципального управления (Kuznetsov, 2000; Sevriugin, 2011; Pudakov, 2017 et al.), в образовании (Bukalerova \& Strebkov, 2012; Borisova, 2013; Damm, 2016 et al.), здравоохранении (Balebanova, 2013; Polukarov, 2013; Plokhov, 2015 et al.), избирательном процесce (Damm, 2006; Kabanov \& Raikov, 2008; Klimova, 2015; Akunchenko, 2018 et al.), спорте (Borisov \& Riabov, 2007; Alekseeva \& Ivanov, 2017 et al.), адвокатуре (Trunov, 2014 et al.), нотариате (Trushkina, 2018 et al.), частном секторе (Nekrasova, 2014 et al.) и др.

Сказанное позволяет сделать вывод о том, что в отечественной науке сформирована добротная основа теоретических знаний о коррупции и способах ее предупреждения. Однако систематизация и упорядочение таких знаний в общепризнанную теорию пока еще не осуществлены. Между тем ведется последовательная работа по научному осмыслению и обобщению накопленных знаний, что находит свое выражение в появлении попыток разработки антикоррупционного права (Surkov, 2013a; Surkov, 2013b; Surkov, 2014 et al.), а также науки корруптологии (Ivanov, 2002 et al.).

Познание феномена безопасности развивается не менее активно. Следует отметить, что в системе теоретических знаний о безопасности трудно выделить преимущественное положение какой-либо науки. Теоретические аспекты безопасности обстоятельно исследованы в философии (Kanishcheva, 2001; Pugin, 2003; Rybalkin, 2003; Koltsov, 2006; Kovalenko, 2008 et al.), политологии (Vozzhenikov, 2002; Klimov, 2003; Shcherbinin, 2003; Kataeva, 2006; Borodin, 2009 et al.), экономике (Mamykina, 2003; Varnavskii, 2003; Agadullin, 2007; Cheskidov, 2013; Firsov, 2019 et al.), социологии (Midova, 1998; Mitrokhina, 1999; Kuznetsov, 2002; Ulianovskii, 2006; Pshidatok, 2012 et al.), праве (Boer, 1998; Pleshakov, 1998; Shchedrin, 2001; Poliakova, 2008; Gorshenkov, 2009 et al.) и др.

Понятийно-категориальный аппарат теории безопасности также интенсивно формируется, причем одной из наиболее обсуждаемых категорий выступает сам феномен безопасности ввиду сложности его природы и многоаспектного содержания. Анализу и содержательному наполнению подвергнуты такие базовые научные категории, как «угроза безопасности» (Korobeinikov, 2009; Mikhailenko \& Gruzdov, 2011; Pleshakov, 2013; Kleimenov, 2018b; Gandaloev, 2020 et al.), «источник повышенной опасности» (Shchedrin, 2008; Dolinskaia, 2009; Rumiantsev, 2011; Zentsova, 2011; Solomin \& Solomina, 2014 et al.), «система обеспечения безопасности» (Kravchuk, 2001; Noskov \& Udilov, 2003; Glazev, 2015; Useev, 2017; Kaliuzhnyi, 2018 et al.) и др.

Научные представления о феномене безопасности формируются как на общетеоретическом уровне, так и в отраслях научного знания. Изучению подлежат правовая безопасность (Galuzin, 2008 et al.), 
криминологическая безопасность (Babaev \& Rakhmanova, 2003 et al.), экономическая безопасность (Zagashvili, 1997 et al.), экологическая безопасность (Burkov \& Shchepkin, et al.), продовольственная безопасность (Rudenko, 2010 et al.) и др.

Развитость межотраслевых познаний безопасности привела к появлению в научной литературе предложений по формированию общей теории безопасности, интегрирующей достижения иных наук (Iarochkin, 2000; Ursul, 2014; Akimov, 2017 et al.).

Таким образом, в отечественной науке сформированы теоретические предпосылки для синтеза и научного осмысления двух взаимосвязанных и взаимообусловленных феноменов «коррупция» и «безопасность» в одной научной категории «антикоррупционная безопасность».

Следует отметить, что использование термина «антикоррупционная безопасность» в научно-практическом обороте осуществляется все чаще (Gorshenkov \& Gorshenkov, 2012; Ivanova, 2013; Panarin \& Parshkov, 2016; Panarin \& Skiba, 2017; Polukarov, 2017; Lebedev, 2018; Kleimenov, 2020 et al.). Одно из первых обсуждений рассматриваемой категории состоялось в рамках V Сибирского антикоррупционного форума «Антикоррупционная безопасность: выявление угроз и стратегия обеспечения» (Damm, Akunchenko, Sukhareva \& Volkova, 2020). Вместе с тем научное осмысление феномена безопасности, ее угроз, а также мер обеспечения в аспекте противодействия коррупции нельзя признать состоявшимся.

Значимый вклад в познание антикоррупционной безопасности внес професcop Н.В. Щедрин, предложивший в работе «Антикоррупционные меры безопасности» авторское определение рассматриваемой категории, а также некоторые ее характеристики (Shchedrin, Damm et al., 2020: 13-77). Антикоррупционная безопасность, в трактовке Н.В. Щедрина, - это «состояние защищенности закрепленных в Конституции РФ системообразующих ценностей социума (объектов охраны) от опасностей, исхо- дящих от противоправных деяний физических лиц и организаций, выполняющих публичные функции или оказывающих публичные услуги вопреки интересам государства и общества, для извлечения противоправной выгоды как для себя, так и для других лиц (источники опасности), а также от деяний всех других лиц и организаций, подкупающих лиц, имеющих публичный статус (источники опасности)» (Shchedrin, Damm et al., 2020: 64).

Под антикоррупционными мерами безопасности автор предлагает понимать «меры принудительного ограничения поведения субъектов коррупции, применяемые при наличии указанных в нормативном правовом акте оснований и имеющие целью защиту общественных отношений от вредоносных коррупционных посягательств» (Shchedrin, Damm et al., 2020: 65). Главным отличием мер безопасности от мер ответственности является то, что они имеют предупредительный и при этом принудительный характер, распространяются на неопределенный круг лиц и применяются при наличии достаточных оснований вне зависимости от виновности (Shchedrin et al., 2010: 31-90). К числу антикоррупционных мер безопасности следует отнести подавляющее большинство антикоррупционных стандартов поведения: запрет на получение подарков в связи с исполнением должностных обязанностей, обязанность принимать меры по предупреждению и урегулированию конфликта интересов и др.

На сегодняшний день антикоррупционные меры безопасности фактически уже представлены во многих отраслях правового регулирования, однако имеют фрагментарный характер и не консолидированы с позиции системного подхода. Этому препятствует отсутствие научных знаний, содержащих системно-структурные характеристики антикоррупционной безопасности как базовой научной категории, а именно понимания сущности данного явления, описания основных объектов антикоррупционной охраны, коррупционных угроз и источников коррупционной 
опасности, а также целей, задач, объектов, субъектов, мер и ресурсов системы обеспечения антикоррупционной безопасности. Последовательное познание названных категорий и их взаимосвязей в межотраслевом аспекте позволит сформировать фундаментальные основы теории антикоррупционной безопасности. Их разработка, в свою очередь, актуализирует определение места, состояния, взаимосвязей и потенциала таких прикладных элементов системы обеспечения антикоррупционной безопасности, как антикоррупционная экспертиза, антикоррупционные стандарты деятельности и поведения, декларирование доходов и расходов, антикоррупционная транспарентность, антикоррупционное просвещение и др.

С учетом особенностей основных объектов охраны, выступающих ключевыми, системообразующими элементами российского общества и государства, предстоит познание антикоррупционной безопасности государственного и муниципального управления, экологической антикоррупционной безопасности, экономической антикоррупционной безопасности, антикоррупционной безопасности избирательного процесса, антикоррупционной безопасности социальной сферы и др.

В свою очередь, в зависимости от степени общественной опасности и интенсивности коррупционных угроз представляется перспективным выделить в качестве самостоятельных направлений развития теоретических знаний следующие основные типы антикоррупционной безопасности:

- антикоррупционная девиантологическая безопасность;

- антикоррупционная деликтологическая безопасность;

- антикоррупционная криминологическая безопасность.

Право на развитие научных знаний в контексте антикоррупционной безопасности также имеет виктимология, поскольку в механизме коррупционного поведения не последнюю роль играет степень виктимности потерпевшего от коррупционного деяния (Kabanov \& Sadeev, 2008; Kabanov,
2017 et al). Представляется, что виктимологическая антикоррупционная безопасность имеет значимый потенциал для участия в построении как общетеоретических основ системы обеспечения антикоррупционной безопасности, так и ее соответствующих отраслевых систем.

Основным преимуществом разработки теории антикоррупционной безопасности является возможность использования междисциплинарного подхода к построению еe системно-структурного содержания. При этом роль первичного координатора и основного идеолога построения нового научного знания должна принадлежать криминологии, поскольку именно эта наука в своем научном аппарате содержит весь необходимый функционал.

\section{Заключение}

Необходимость сдерживания и поступательного снижения уровня коррупции в Российской Федерации обусловила формирование и совершенствование законодательства о противодействии коррупции, а также институционализацию управленческих структур, обеспечивающих соблюдение соответствующего законодательства.

Наблюдение за системой противодействия коррупции в Российской Федерации позволяет сделать вывод об опережающем развитии антикоррупционного законодательства и правоприменения и некотором отставании научного обоснования противодействия коррупции. Сложившаяся система практически достигла пределов своего расширения, и для выхода на новый уровень предупредительной деятельности требуется поиск новых фундаментальных подходов.

Основная проблема сложившейся системы противодействия коррупции заключается в отсутствии единой концептуально-методологической основы антикоррупционной деятельности, позволяющей в рамках одной руководящей идеи обобщить межотраслевые научные наработки, а также оценить соответствие сложившейся практической модели поставленным задачам. 
Формирование новой стратегии антикоррупционной безопасности должно опираться на межотраслевые научные философские, правовые, экономические, социальные, политологические, психологические достижения и в поступательном их развитии соединиться в единую упорядоченную систему знаний - теорию антикоррупционной безопасности. В системе научного знания достаточными ресурсами для обеспечения общей первичной координации познавательных процессов обладает наука криминология.

Построение теории антикоррупционной безопасности - сложный и ресурсоемкий процесс, меняющий мировоззренческие и концептуальнометодологические подходы к вопросам научного обеспечения и организации практической антикоррупционной дея- тельности. Теоретическое осмысление научных достижений и оптимизация имеющихся ресурсов в контексте антикоррупционной безопасности позволят сформировать новую научную платформу для построения межотраслевой системы обеспечения личной, государственной, а в перспективе и глобальной антикоррупционной безопасности.

В завершение футурологического прогнозирования развития системы междисциплинарных антикоррупционных знаний представляется возможным отметить, что смелость научной идеи не должна граничить с научным безрассудством. Вместе с тем когнитивное научное творчество выступает залогом прогрессивного развития научных знаний. Главное правило исследователя - «Per aspera ad astra» (с лат. - через тернии к звездам).

\section{Список литературы / References}

Abramova, M.V. (2012). K voprosu o sushchnosti poniatiia «korruptsionnye riski» [On the question of the essence of the concept of «corruption risks»], In Aktualnye problemy rossiiskogo prava [Actual problems of Russian Law], 4, 69-73.

Agadullin, N.F. (2007). Natsionalnaia ekonomicheskaia bezopasnost kak kategoriia ekonomicheskoi teorii [National economic security as a category of economic theory], PhD diss. Ufa, $165 \mathrm{p}$.

Akhmetova, N.A. (2006). Sotsialnyi mekhanizm vosproizvodstva korruptsii v usloviiakh sovremennogo rossiiskogo obshchestva [The social mechanism of corruption reproduction in the conditions of modern Russian society], PhD diss. Volgograd, 164 p.

Akimov, V.A. (2017). Nauchnye osnovy obshchei teorii bezopasnosti [Scientific bases of the general theory of security], In Tekhnologii grazhdanskoi bezopasnosti [Technologies of civil security], 4, 4-9.

Akunchenko, E.A. (2018). Kriminologicheskaia kharakteristika i preduprezhdenie korruptsionnoi prestupnosti v izbiratelnom protsesse Rossiiskoi Federatsii [Criminological characteristics and prevention of corruption crime in the electoral process of the Russian Federation], PhD diss. Krasnoyarsk, 272 p.

Alakshina, I.S. (2005). Korruptsiia kak element sotsialnoi deistvitelnosti sovremennogo rossiiskogo obshchestva [Corruption as an element of the social reality of modern Russian society], PhD diss. Krasnodar, $133 \mathrm{p}$.

Aleksandrov, S.G. (2005). Pravovoi mekhanizm borby politsii s korruptsiei: sravnitelno-pravovoe issledovanie na primere Rossiiskoi Federatsii i vedushchikh zarubezhnykh stran [The legal mechanism of the police's fight against corruption: a comparative legal study on the example of the Russian Federation and leading foreign countries], Dr. Sci. diss. Moscow, 314 p.

Aleksandrova, I.A. (2016). Sovremennaia ugolovnaia politika po obespecheniiu ekonomicheskoi bezopasnosti i protivodeistviiu korruptsii [Modern criminal policy for ensuring economic security and combating corruption], Dr. Sci. diss. Nizhny Novgorod, 727 p.

Alekseev, S.V. (2008). Korruptsiia v perekhodnom obshchestve: sotsiologicheskii analiz [Corruption in a transitional society: a sociological analysis], Dr. Sci. diss. Novocherkassk, $411 \mathrm{p}$.

Alekseeva, A.P., Ivanov, A.S. (2014). Korruptsiia v sfere sporta [Corruption in the field of sports]. Volgograd, VA MVD Rossii, 254 p. 
Artemev, A.B. (2014). Korruptsiia v mekhanizme funktsionirovaniia gosudarstva (teoretiko-pravovoe issledovanie $\mathrm{v}$ ramkakh evoliutsionnogo podkhoda) [Corruption in the mechanism of state functioning (theoretical and legal research within the framework of the evolutionary approach)], Dr. Sci. diss. Moscow, 438 p.

Astanin, V.V. (2009). Antikorruptsionnaia politika Rossii: kriminologicheskie aspekty [Anti-corruption policy of Russia: criminological aspects], Dr. Sci. diss. Moscow, 382 p.

Astanin, V.V. (2012). Antikorruptsionnaia politika Rossii. Kriminologicheskie aspekty [Anticorruption policy of Russia. Criminological aspects]. Moscow, Unity-Dana, 255 p.

Astanin, V.V. (2016). Antikorruptsionnaia ekspertiza zakonodatelstva v razvitii praktiki i metodiki [Anti-corruption expertise of legislation in the development of practice and methodology], In Monitoring pravoprimeneniia [Monitoring of law enforcement], 3, 4-8. DOI: 10.21681/2226-0692-2016-3-04-08.

Babaev, M.M., Rakhmanova, E.N. (2003). Prava cheloveka i kriminologicheskaia bezopasnost [Human rights and criminological security]. Moscow, Logos, 153 p.

Balebanova, T.A. (2013). Sovremennoe sostoianie korruptsii v zdravookhranenii Rossii i mery ee preduprezhdeniia: kriminologicheskoe issledovanie [The current state of corruption in Russian healthcare and measures to prevent it: criminological research], PhD diss. Moscow, $205 \mathrm{p}$.

Belov, V.V. (2008). Rasprostranenie korruptsii v sisteme organov gosudarstvennoi vlasti Rossii: etapy i problemy borby v 1992-2000 gg. [The spread of corruption in the system of state authorities of Russia: stages and problems of struggle in 1992-2000], PhD diss. Moscow, $234 \mathrm{p}$.

Belskii, K.S. (2012). Ob utochnenii poniatiia «korruptsiia» [On clarifying the concept of «corruption»], In Gosudarstvo i parvo [State and law], 12, 22-28.

Bikeev, I.I., Kabanov, P.A. (2019). Antikorruptsionnoe prosveshchenie: voprosy teorii i praktiki [Anticorruption enlightenment: issues of theory and practice]. Kazan, Poznanie, 240 p.

Boer, V.M. (1998). Informatsionno-pravovaia politika i bezopasnost Rossii: teoretiko-pravovoi aspekt [Information and legal policy and security of Russia: theoretical and legal aspect], Dr. Sci. diss. Saint Petersburg, $392 \mathrm{p}$.

Bogunov, S.S. (2012). Korruptsiia v sovremennoi Rossii: politologicheskii analiz [Corruption in modern Russia: a political analysis], PhD diss. Moscow, 169 p.

Borisov, O.A., Riabov, A.S. (2007). Korruptsiia i sport: kriminologicheskii analiz problemy [Corruption and sport: criminological analysis of the problem], In Vestnik volgogradskoi akademii MVD Rossii [Herald of the Volgograd Academy of the Ministry of Internal Affairs of Russia], 2, 116-120.

Borisova, E.A. (2013). Korruptsiia v sisteme vysshego obrazovaniia: perspektivy sotsialnogo kontrolia (regionalnyi aspekt) [Corruption in the system of higher education: prospects of social control (regional aspect)], $\mathrm{PhD}$ diss. Moscow, $222 \mathrm{p}$.

Borodin, A.S. (2009). Informatsionnaia bezopasnost v sovremennoi Rossii: politologicheskii analiz [Information security in modern Russia: a political analysis], PhD diss. Saint Petersburg, 211 p.

Bratanovskii, S.N., Zelenov, M.F. (2011). Poniatie, sostav i vidy korruptsionnykh pravonarushenii [The concept, composition and types of corruption offenses], In Grazhdanin i parvo [Citizen and law], 11, 23-31.

Bratanovskii, S.N., Zelenov, M.F. (2017). Neobkhodimost sistemnogo podkhoda k protivodeistviiu korruptsii na gosudarstvennoi i munitsipalnoi sluzhbe [The need for a systematic approach to combating corruption in the state and municipal service], In Gosudarstvo i parvo [State and law], 1, 103-108.

Budagov, E.S. (2012). Psikhologo-pravovye mekhanizmy formirovaniia antikorruptsionnoi kompetentnosti sotrudnikov UVD [Psychological and legal mechanisms for the formation of anti-corruption competence of Internal Affairs Department employees], PhD diss. Moscow, $185 \mathrm{p}$.

Bukalerova, L.A., Strebkov, Iu.P. (2012). Korruptsionnye prestupleniia v sfere obrazovaniia [Corruption crimes in the field of education]. Moscow, NII SP, $155 \mathrm{p}$.

Burkov, V.N., Shchepkin, A.V. (2003). Ekologicheskaia bezopasnost [Ecological safety]. Moscow, IPU RAN, $90 \mathrm{p}$.

Bush, M. Iu. (2006) Politicheskii aspekt korruptsionnykh otnoshenii v sovremennoi Rossii [The political aspect of corruption relations in modern Russia], PhD diss. Rostov-on-Don, 142 p. 
Cheskidov, M.A. (2013). Ekonomicheskaia bezopasnost gosudarstva v usloviiakh informatsionnoi ekonomiki [Economic security of the state in the conditions of the information economy], PhD diss. Saratov, $173 \mathrm{p}$.

Damm, I.A. (2003). Poniatie, priznaki i vidy korruptsii [The concept, signs and types of corruption], In Preduprezhdenie korruptsii v sisteme ugolovnoi iustitsii [Prevention of corruption in the criminal justice system]. Krasnoyarsk, 117-127.

Damm, I.A. (2006). Korruptsiia v rossiiskom izbiratelnom protsesse: poniatie i protivodeistvie [Corruption in the Russian electoral process: the concept and counteraction], PhD diss. Krasnoyarsk, 249 p.

Damm, I.A. (2016). Korruptsiia v sfere obrazovaniia: poniatie, kharakternye cherty, formy i vidy [Corruption in the field of education: concept, characteristic features, forms and types], In Aktualnye problemy ekonomiki i prava [Actual problems of economics and law], 4, 5-17. DOI: 10.21202/1993-047X.10.2016.4.517.

Damm, I.A. (2018a). Antikorruptsionnoe prosveshchenie v obrazovatelnoi organizatsii vysshego obrazovaniia: osnovnye napravleniia i problemy realizatsii [Anti-corruption enlightenment in the educational organization of higher education: the main directions and problems of implementation], In Administrativnoe i munitsipalnoe parvo [Administrative and municipal law], 6, 36-48. DOI: 10.7256/2454-0595.2018.6.26763.

Damm, I.A. (2018b). Protivodeistvie korruptsii: voprosy poniatiino-kategorialnogo apparata [Anticorruption: issues of conceptual and categorical apparatus], In Voprosy bezopasnosti [Questions of security], 3, 22-33. DOI: 10.25136/2409-7543.2018.3.26684.

Damm, I.A. (2020). Korruptsionnoe prestuplenie: problemy ponimaniia i opredeleniia [Corruption crime: problems of understanding and definition], In Akademicheskii iuridicheskii zhurnal [Academic Law Journal], 1, 20-27.

Damm, I.A., Akunchenko, E.A., Sukhareva, K.S., Volkova, M.A. (2020). Antikorruptsionnaia bezopasnost: vyiavlenie ugroz i strategiia obespecheniia (obzor V Sibirskogo antikorruptsionnogo foruma) [Anti-corruption security: identification of threats and a strategy for ensuring (review of the V Siberian Anti-Corruption Forum)], In Voprosy bezopasnosti [Security issues], 1, 59-78. DOI: 10.25136/24097543.2020.1.31887.

Dolinskaia, V.V. (2009). Istochniki povyshennoi opasnosti [Sources of increased danger], In Zakony Rossii: opyt, analiz, praktika [Laws of Russia: experience, analysis, practice], 9, 48-56.

Dronov, R.V. (2013). Mekhanizm neitralizatsii korruptsii v organakh gosudarstvennogo upravleniia [The mechanism of neutralization of corruption in public administration bodies], Dr. Sci. diss. Saint Petersburg, $323 \mathrm{p}$.

Egorova, N.A. (2013). Korruptsionnye prestupleniia: poniatie, vidy, problemy kvalifikatsii [Corruption crimes: concept, types, problems of qualification], In Rossiiskii ezhegodnik ugolovnogo prava [Russian Yearbook of Criminal Law], 7, 286-326.

Firsov, D.A. (2019). Metodologiia obespecheniia ekonomicheskoi bezopasnosti v usloviiakh formirovaniia i realizatsii proizvodnykh investitsionnykh proektov [Methodology of ensuring economic security in the conditions of formation and implementation of derivative investment projects], Dr. Sci. diss. Moscow, 315 p.

Galuzin, A.F. (2008). Pravovaia bezopasnost i ee printsipy [Legal security and its principles]. Saint Petersburg, Iuridicheskii tsentr Press, 358 p.

Gandaloev, R.B. (2020). Poniatie ugroz voennoi bezopasnosti Rossiiskoi Federatsii [The concept of threats to military security of the Russian Federation], In Zakon i parvo [Legislation and Law], 11, 40-43. DOI: $10.24411 / 2073-3313-2020-10516$.

Glazev, S. Iu. (2015). Sozdanie sistemy obespecheniia ekonomicheskoi bezopasnosti i upravleniia razvitiem Rossii [Creation of a system for ensuring economic security and managing the development of Russia], In Menedzhment i biznes-administrirovanie [Management and business administration], 4, 12-26.

Goncharenko, G.S. (2008). Lichnost korruptsionnogo prestupnika [The personality of a corrupt criminal], In Izvestiia vysshikh uchebnykh zavedenii. Severo-Kavkazskii region. Obshchestvennye nauki [News of higher educational institutions. The North Caucasus region. Social sciences], 4, 108-111. 
Gorbova, V.V. (2016) Filosofsko-antropologicheskie izmereniia korruptsii [Philosophical and anthropological dimensions of corruption], $\mathrm{PhD}$ diss. Voronezh, 2016. $137 \mathrm{p}$.

Gorshenkov, A.G., Gorshenkov, G.N. (2012). Antikorruptsionnaia bezopasnost politseiskogo [Anticorruption security of a policeman], In Iuridicheskaia nauka i praktika: Vestnik Nizhegorodskoi akademii MVD Rossii [Legal science and practice: Herald of the Nizhny Novgorod Academy of the Ministry of Internal Affairs of Russia], 4, 60-64.

Gorshenkov, G.G. (2009). Antikriminalnaia bezopasnost lichnosti [Anti-criminal security of the individual], Dr. Sci. diss. Stavropol, 421 p.

Gorshenkov, G.N. (2014). Politika protivodeistviia korruptsii [Anti-corruption policy], In Biznes. Obrazovanie. Pravo [Business. Education. Law], 2, 62-67.

Gribkov, M.A. (2012). Gosudarstvennoe upravlenie protsessami protivodeistviia korruptsii [State management of anti-corruption processes], PhD diss. Moscow, $244 \mathrm{p}$.

Iarochkin, V.I. (2000). Sekiuritologiia: nauka o bezopasnosti zhiznedeiatelnosti [Securitology: the science of life safety]. Moscow, Os-89, 399 p.

Ilii, S.K. (2015). Administrativnye pravonarusheniia korruptsionnoi napravlennosti [Administrative corruption-related offenses], In Administrativnoe i munitsipalnoe parvo [Administrative and municipal law], 5, 460-468. DOI: 10.7256/1999-2807.2015.5.12588.

Iukhachev, S.P. (2010). Korruptsiia kak ekonomicheskie otnosheniia sotsiuma [Corruption as economic relations of society], Dr. Sci. diss. Tambov, 291 p.

Ivanov, A.M. (2002). Korruptologiia - pravovaia nauka i uchebnaia distsiplina: put sovershenstvovaniia ugolovnoi politiki i zakonodatelstva o vozdeistvii na organizovannuiu prestupnost i korruptsiiu [Corruptology - legal science and academic discipline: the way to improve criminal policy and legislation on the impact on organized crime and corruption]. Vladivostok, Agentstvo Vremia LTD, 277 p.

Ivanova, A.A. (2013). Antikorruptsionnaia bezopasnost kak strategicheskaia tsel politiki protivodeistviia korruptsii i obieekt monitoringovogo kontrolia [Anti-corruption security as a strategic goal of the anti-corruption policy and the object of monitoring control], In Iuridicheskaia nauka i praktika: Vestnik Nizhegorodskoi akademii MVD Rossii [Legal science and practice: Herald of the Nizhny Novgorod Academy of the Ministry of Internal Affairs of Russia], 24, 74-79.

Izotov, M.O. (2012). Korruptsiia v sovremennoi Rossii: sotsiokulturnye osnovaniia i formy proiavleniia [Corruption in modern Russia: socio-cultural foundations and forms of manifestation], PhD diss. Orel, $192 \mathrm{p}$.

Kabanov, P.A. (2014). Kriminologicheskii monitoring lichnosti korruptsionnogo prestupnika (na materialakh Respubliki Belarus) [Criminological monitoring of the personality of a corrupt criminal (on the materials of the Republic of Belarus)], In Monitoring pravoprimeneniia [Monitoring of law enforcement], 3, 19-24.

Kabanov, P.A. (2015). Poniatie i soderzhanie antikorruptsionnogo prosveshcheniia kak sredstva profilaktiki korruptsii [The concept and content of anti-corruption enlightenment as a means of preventing corruption], In Iuridicheskie issledovaniia [Legal research], 2, 12-27. DOI: 10.7256/24097136.2015.2.14150.

Kabanov, P.A. (2017). Viktimologicheskoe antikorruptsionnoe prosveshchenie: poniatie, soderzhanie, formy i sredstva osushchestvleniia [Victimological anti-corruption enlightenment: concept, content, forms and means of implementation], In Iuridicheskie issledovaniia [Legal research], 6, 38-64. DOI: 10.25136/2409-7136.2017.6.23077.

Kabanov, P.A. (2018). Antikorruptsionnoe protsessualnoe zakonodatelstvo subieektov Rossiiskoi Federatsii: formirovanie i soderzhanie [Anti-corruption procedural legislation of the subjects of the Russian Federation: formation and content], In Aktualnye problemy ekonomiki i prava [Actual problems of economics and law], 12 (2), 300-333. DOI: 10.21202/1993-047X.12.2018.2.300-333.

Kabanov, P.A. (2019). Korruptsionnyi risk kak pravovaia kategoriia, ispolzuemaia v regionalnykh i munitsipalnykh normativnykh pravovykh aktakh [Corruption risk as a legal category used in regional and municipal regulatory legal acts], In Iuridicheskaia tekhnika [Legal technique], 13, 462-471. 
Kabanov, P.A., Raikov, G.I. (2008). Elektoralnaia korruptsiia i formy ee proiavleniia: opyt politikokriminologicheskogo analiza [Electoral corruption and the forms of its manifestation], In Sledovatel [Detective], 10, 21-25.

Kabanov, P.A., Sadeev, M.M. (2008). Viktimologiia korruptsii kak chastnaia viktimologicheskaia teoriia: poniatie, predmet i nekotorye zadachi, sviazannye s okazaniem pomoshchi zhertvam korruptsii [Victimology of corruption as a private victimological theory: concept, subject and some tasks related to providing assistance to victims of corruption], In Sledovatel [Detective], 5, 43-46.

Kaliuzhnyi, Iu.N. (2018). Soderzhatelnaia kharakteristika osnovnykh elementov sistemy obespecheniia bezopasnosti dorozhnogo dvizheniia [Substantive characteristics of the main elements of the road safety system], In Pravo i politika [Law and politics], 7, 36-46. DOI: 10.7256/2454-0706.2018.7.20669.

Kanishcheva, Zh.N. (2001). Vnutrenniaia bezopasnost obshchestva [Internal security of society], PhD diss. Moscow, $134 \mathrm{p}$.

Kapinus, O.S. (2018). Kriminologicheskoe issledovanie lichnosti korruptsionnogo prestupnika [Criminological research of the personality of a corrupt criminal], In Zhurnal zarubezhnogo zakonodatelstva $i$ sravnitelnogo pravovedeniia [Journal of Foreign Legislation and Comparative Jurisprudence], 1, 95-101. DOI: $10.12737 /$ art.2018.1.13 .

Kataeva, E.G. (2006). Energeticheskaia bezopasnost kak uslovie ustoichivogo razvitiia Rossii [Energy security as a condition for sustainable development of Russia], PhD diss. Moscow, $331 \mathrm{p}$.

Khabrieva, T. Ia. (2009). Formirovanie pravovykh osnov antikorruptsionnoi ekspertizy normativnykh pravovykh aktov [Formation of legal bases of anti-corruption expertise of normative legal acts], In Zhurnal rossiiskogo prava [Journal of Russian Law], 13 (10), 5-13.

Khabrieva, T. Ia. (2012). Korruptsiia i pravo: doktrinalnye podkhody k postanovke problemy [Corruption and law: doctrinal approaches to the problem statement], In Zhurnal rossiiskogo prava [Journal of Russian Law], 16 (6), 5-17.

Khabrieva, T. Ia., Chernogor, N.N. (2017). Ukreplenie pravoporiadka i protivodeistvie korruptsii v usloviiakh evraziiskoi integratsii [Strengthening the rule of law and combating corruption in the conditions of Eurasian integration], In Obshchestvennye nauki i sovremennost [Social sciences and modernity], 1, 5-19.

Khairutdinova, L.R. (2015). Antikorruptsionnoe prosveshchenie: poniatie, tseli i znachenie [Anticorruption enlightenment: the concept, goals and meaning], In Gumanitarnye nauchnye issledovaniia [Humanitarian scientific research], 1-1, 106-109.

Khamdeev, A.R. (2014). Pedagogicheskoe obespechenie formirovaniia antikorruptsionnoi kultury studentov vuza [Pedagogical support for the formation of anti-corruption culture of university students], PhD diss. Kazan, $340 \mathrm{p}$.

Kharitonova, V.N. (2013). Klientelizm v gosudarstvennoi sluzhbe: prichiny i puti ogranicheniia [Clientelism in the public service: reasons and ways of restriction], PhD diss. Moscow, $170 \mathrm{p}$.

Kiselev, V.V. (2016). Psikhologicheskie determinanty antikorruptsionnogo povedeniia sotrudnikov gosudarstvennoi organizatsii [Psychological determinants of anti-corruption behavior of employees of a state organization], PhD diss. Moscow, $258 \mathrm{p}$.

Kleimenov, M.P. (2018a). Kriminologicheskoe zakonodatelstvo i kriminologicheskoe pravo v Rossii [Criminological legislation and criminological law in Russia], In Lex russica, 2, 148-159. DOI: 10.17803/1729-5920.2018.135.2.148-159.

Kleimenov, M.P. (2018b). Ugrozy kriminologicheskoi bezopasnosti [Threats to criminological security], In Aktualnye problemy iurisprudentsii [Actual problems of jurisprudence]. Novosibirsk, 45-51.

Kleimenov, M.P. (2020). Aktualnye napravleniia obespecheniia antikorruptsionnoi bezopasnosti [Actual directions of ensuring anti-corruption security], In Antikorruptsionnaia bezopasnost: vyiavlenie ugroz i strategiia obespecheniia [Anti-corruption security: threat identification and security strategy]. Krasnoyarsk, $115-120$.

Kleimenov, M.P., Kharitonov, A.N. (2018). Vozdeistvie mezhdunarodnogo soobshchestva na protivodeistvie korruptsii v Rossii [The impact of the international community on combating corruption in Russia], 
In Ugolovnoe sudoproizvodstvo: problemy teorii i praktiki [Criminal proceedings: problems of theory and practice], 3, 41-48.

Kleimenov, M.P., Kleimenov, I.M. (2017). Globalizatsiia i ugrozy natsionalnoi bezopasnosti [Globalization and threats to national security], In Pravoprimenenie [Law enforcement], 1 (2), 164-174. DOI: 10.24147/2542-1514.2017.1(2).164-174.

Klimov, O.N. (2003). Natsionalnaia bezopasnost Rossii v usloviiakh globalizatsii: politologicheskii analiz [The national security of Russia in the conditions of globalization: a political analysis], PhD diss. Moscow, $169 \mathrm{p}$.

Klimova, Iu.N. (2015). Antikorruptsionnoe napravlenie bezopasnosti subieektov izbiratelnogo prava [Anti-corruption direction of security of subjects of electoral law], In Vestnik Vladimirskogo gosudarstvennogo universiteta. Seriia: IUridicheskie nauki [Herald of the Vladimir State University. Series: Legal Sciences], 2, 78-90.

Kliukovskaia, I.N. (2004). Teoreticheskie osnovy kriminologicheskogo issledovaniia antikorruptsionnoi politiki [Theoretical foundations of criminological research of anti-corruption policy], Dr. Sci. diss. Moscow, $353 \mathrm{p}$.

Koltsov, V.A. (2006). Filosofskie osnovy kontseptsii natsionalnoi bezopasnosti [Philosophical foundations of the concept of national security], PhD diss. Nizhny Novgorod, $178 \mathrm{p}$.

Kondratenko, G.G. (2016). Antikorruptsionnaia bezopasnost stolichnogo megapolisa: sotsialnofilosofskii analiz [Anti-corruption security of the metropolitan metropolis: socio-philosophical analysis], PhD diss. Moscow, $220 \mathrm{p}$.

Korobeinikov, A.A. (2009). Novye ugrozy - novoe poniatie bezopasnosti [New threats - a new concept of security], In Pravo i bezopasnost [Law and security], 3-32, 87-90.

Korobkin, A.N. (2012). Problemy osushchestvleniia nezavisimoi antikorruptsionnoi ekspertizy [Problems of implementation of independent anti-corruption expertise], In Zhurnal rossiiskogo prava [Journal of Russian Law], 16 (9), 60-65.

Kovalenko, M.P. (2008). Strategiia obespecheniia natsionalnoi bezopasnosti Rossii: sotsialnofilosofskii analiz protivodeistviia ugrozam [Strategy of ensuring the national security of Russia: sociophilosophical analysis of countering threats], PhD diss. Rostov-on-Don, $172 \mathrm{p}$.

Kozlov, T.L. (2020). Perspektivy razvitiia rossiiskogo zakonodatel'stva o protivodeistvii korruptsii [Prospects for the development of Russian legislation on combating corruption], In Zhurnal rossiiskogo prava [Journal of Russian Law], 24 (5), 158-166. DOI: 10.12737/jrl.2020.063.

Kravchuk, I.L. (2001). Teoreticheskie osnovy i metody formirovaniia sistemy obespecheniia bezopasnosti proizvodstva gornodobyvaiushchego predpriiatiia [Theoretical foundations and methods of forming a system for ensuring the safety of production of a mining enterprise], Dr. Sci. diss. Moscow, $274 \mathrm{p}$.

Kudashkin, A.V., Kozlov, T.L. (2010). Eshche raz o pravovom poniatii korruptsii [Once again about the legal concept of corruption], In Sovremennoe parvo [Modern law], 6, 3-8.

Kuligin, O.V. (2012). Istoricheskii opyt gosudarstvennogo i obshchestvennogo protivodeistviia korruptsii v Rossiiskoi Federatsii: 1991-2008 gg. [Historical experience of state and public anti-corruption in the Russian Federation: 1991-2008], PhD diss. Astrakhan, 207 p.

Kurakin, A.V. (2008). Administrativno-pravovye sredstva preduprezhdeniia i presecheniia korruptsii v sisteme gosudarstvennoi sluzhby Rossiiskoi Federatsii [Administrative and legal means of preventing and suppressing corruption in the public service system of the Russian Federation], Dr. Sci. diss. Lyubertsy, $432 \mathrm{p}$.

Kuznetsov, I.E. (2000). Korruptsiia v sisteme gosudarstvennogo upravleniia: sotsiologicheskoe issledovanie [Corruption in the public administration system: a sociological study], PhD diss. Saint Petersburg, $170 \mathrm{p}$.

Kuznetsov, M.R. (2002). Formirovanie kultury bezopasnosti v transformiruiushchemsia obshchestve: sotsiologicheskii aspekt [The formation of a security culture in a transforming society: a sociological aspect], Dr. Sci. diss. Moscow, 388 p.

Lebedev, S. Ia. (2018). Razvitie innovatsionnykh tekhnologii v antikorruptsionnoi bezopasnosti [Development of innovative technologies in anti-corruption security], In Ugolovnoe sudoproizvodstvo: problemy teorii i praktiki [Criminal proceedings: problems of theory and practice], 1, 52-55. 
Leonteva, E.O. (2010). Institualizatsiia neformalnykh praktik v sfere vysshego obrazovaniia [Institutionalization of informal practices in the field of higher education], Dr. Sci. diss. Khabarovsk, $352 \mathrm{p}$.

Makarov, V.V. (2008). Korruptsiia kak ugroza ekonomicheskoi bezopasnosti Rossii [Corruption as a threat to the economic security of Russia], PhD diss. Moscow, $173 \mathrm{p}$.

Mamykina, A.P. (2003). Teoretiko-metodologicheskie aspekty ekonomicheskoi bezopasnosti [Theoretical and methodological aspects of economic security], PhD diss. Moscow, $133 \mathrm{p}$.

Markosian, G.M. (2010). Korruptsiia v SSSR v 1920-e gody i borba s nei [Corruption in the USSR in the 1920s and the fight against it], PhD diss. Moscow, $214 \mathrm{p}$.

Markuntsov, S.A. (2021). O prestupleniiakh korruptsionnoi napravlennosti i korruptsionnykh prestupleniiakh [On corruption-related crimes and corruption crimes], In Problemy ugolovnoi otvetstvennosti i nakazaniia [Problems of criminal responsibility and punishment]. Ryazan, 80-88.

Matskevich, I.M., Antonian, E.A., Aminov, I.I. (2017). Mekhanizmy protivodeistviia korruptsionnym riskam $\mathrm{v}$ uchrezhdeniiakh, ispolniaiushchikh nakazaniia [Mechanisms of countering corruption risks in institutions executing punishments]. Moscow, Nauchnyi Konsultant, 177 p.

Midova, V.N. (1998). Problema pravovogo regulirovaniia bezopasnosti lichnosti v usloviiakh sovremennoi Rossii [The problem of legal regulation of personal security in the conditions of modern Russia], $\mathrm{PhD}$ diss. Rostov-on-Don, $121 \mathrm{p}$.

Mikhailenko, A.N., Gruzdov, S.V. (2011). Poniatiia ugrozy i vyzova natsionalnoi bezopasnosti [Concepts of threat and challenge to national security], In Obozrevatel [Observer], 2, 57-63.

Mikhailov, V.I. (2021). Soglasovanie zapretov i dozvolenii, ustanovlennykh v tseliakh protivodeistviia korruptsii, kak mezhdistsiplinarnaia problema [Coordination of prohibitions and permits established for the purpose of countering corruption as an interdisciplinary problem], In Zhurnal rossiiskogo prava [Journal of Russian Law], 25 (6), 117-130. DOI: 10.12737/jrl.2021.078

Mitrokhina, E. Iu. (1999). Informatsionnaia bezopasnost lichnosti kak sotsiologicheskaia problema [Information security of the individual as a sociological problem], PhD diss. Moscow, $156 \mathrm{p}$.

Muzalevskaia, E.A. (2006) Korruptsiia v sisteme gosudarstvennoi sluzhby v Rossii: istoki i tendentsii (1992-2005 gg.) [Corruption in the public service system in Russia: origins and trends (1992-2005)], PhD diss. Moscow, 219 p.

Naumov, Iu.G. (2014). Teoriia i metodologiia protivodeistviia institutsionalnoi korruptsii [Theory and methodology of countering institutional corruption], Dr. Sci. diss. Moscow, 325 p.

Nekrasova, T.A. (2014). Korruptsionnaia prestupnost v kommercheskikh organizatsiiakh: kriminologicheskaia kharakteristika i preduprezhdenie [Corruption crime in commercial organizations: criminological characteristics and prevention], $\mathrm{PhD}$ diss. Moscow, $158 \mathrm{p}$.

Nomokonov, V.A. (2013). Korruptsiia v mire i Rossii: sostoianie i problemy protivodeistviia [Corruption in the world and Russia: the state and problems of counteraction], In Aziatsko-tikhookeanskii region: ekonomika, politika, parvo [The Asia-Pacific region: economics, politics, law], 15 (2), 103-111.

Nomokonov, V.A. (2016) Rossiiskaia politika v sfere protivodeistviia korruptsii: skoree korruptsiogenna, chem optimalna? [Russian anti-corruption policy: is it more corrupt than optimal?], In Prestupnost, ugolovnaia politika, zakon [Crime, criminal policy, law]. Moscow, 314-320.

Noskov, S.I., Udilov, V.P. (2003). Upravlenie sistemoi obespecheniia pozharnoi bezopasnosti na regionalnom urovne [Management of the fire safety system at the regional level]. Irkutsk, $151 \mathrm{p}$.

Panarin, D.A., Parshkov, A.V. (2016). K voprosu o normativno-pravovom regulirovanii pravootnoshenii v sfere antikorruptsionnoi bezopasnosti [On the issue of regulatory and legal regulation of legal relations in the field of anti-corruption security], In Prikladnaia iuridicheskaia psikhologiia [Applied legal psychology], 3, 137-145.

Panarin, D.A., Skiba, A.P. (2017). Nekotorye voprosy normativno-pravovogo regulirovaniia spornykh pravootnoshenii $\mathrm{v}$ sfere antikorruptsionnoi bezopasnosti [Some issues of regulatory regulation of disputed legal relations in the field of anti-corruption security], In Vestnik Kuzbasskogo instituta [Herald of the Kuzbass Institute], 1, 88-95. 
Pechenkin, V.A. (2012). Formirovanie antikorruptsionnoi kompetentnosti gosudarstvennykh sluzhashchikh [Formation of anti-corruption competence of civil servants], $\mathrm{PhD}$ diss. Moscow, $212 \mathrm{p}$.

Pleshakov, V.A. (1998). Kriminologicheskaia bezopasnost i ee obespechenie v sfere vzaimovliianiia organizovannoi prestupnosti i prestupnosti nesovershennoletnikh [Criminological security and its provision in the sphere of mutual influence of organized crime and juvenile delinquency], Dr. Sci. diss. Moscow, 1998. $323 \mathrm{~s}$.

Pleshakov, V.A. (2013). Ugrozy kriminologicheskoi bezopasnosti: sistemnyi analiz sovremennogo sostoianiia [Threats to criminological security: a system analysis of the current state], In Chelovek: prestuplenie i nakazanie [Human: crime and punishment], 3, 34-39.

Plokhov, S.V. (2015). Protivodeistvie korruptsionnoi prestupnosti v sotsialnoi sfere: kriminologicheskii analiz korruptsii v oblastiakh zdravookhraneniia i obrazovaniia [Countering corruption crime in the social sphere: criminological analysis of corruption in the fields of healthcare and education]. Moscow, Iurlitinform, $261 \mathrm{p}$.

Poliakov, M.M. (2015). Korruptsionnye administrativnye pravonarusheniia: poniatie, vidy i soderzhanie [Corruption administrative offenses: concept, types and content], In Vestnik Universiteta imeni O. E. Kutafina (MGIUA) [Herald of the Kutafin University (MSLA)], 8, 209-215.

Poliakova, T.A. (2008). Pravovoe obespechenie informatsionnoi bezopasnosti pri postroenii informatsionnogo obshchestva $\mathrm{v}$ Rossii [Legal support of information security in the construction of an information society in Russia], Dr. Sci. diss. Moscow, 438 p.

Polukarov, A.V. (2013). Ugolovno-pravovye i kriminologicheskie mery protivodeistviia korruptsii v sfere zdravookhraneniia [Criminal-legal and criminological measures to combat corruption in the field of healthcare], $\mathrm{PhD}$ diss. Moscow, $225 \mathrm{p}$.

Polukarov, A.V. (2017). Antikorruptsionnaia bezopasnost sotsialnoi sfery [Anti-corruption security of the social sphere], In Politseiskaia deiatelnost [Police activity], 1, 116-126. DOI: 10.7256/24540692.2017.1.17949.

Polukarov, A.V. (2020). Administrativno-pravovoe regulirovanie protivodeistviia korruptsii v sotsialnoi sfere [Administrative and legal regulation of combating corruption in the social sphere], Dr. Sci. diss. Moscow, $594 \mathrm{p}$.

Pomazuev, A.E. (2016). Korruptsionnye riski: poniatie i znachenie dlia mekhanizma protivodeistviia korruptsii [Corruption risks: the concept and significance for the anti-corruption mechanism], In Elektronnoe prilozhenie $k$ «Rossiiskomu iuridicheskomu zhurnalu» [Electronic supplement to «Russian Juridical Journal»], 2, 62-69.

Prokuratov, V.N. (2015). Politicheskie mekhanizmy protivodeistviia korruptsii v sovremennoi Rossii: sostoianie, perspektivy razvitiia [Political mechanisms of combating corruption in modern Russia: state, prospects of development], PhD diss. Orel, $179 \mathrm{p}$.

Pshenichniuk, D.V. (2017). Psikhologicheskie usloviia formirovaniia u studentov sposobov raspoznavaniia korruptsionnogo povedeniia [Psychological conditions for the formation of methods of recognizing corrupt behavior among students], $\mathrm{PhD}$ diss. Moscow, $266 \mathrm{p}$.

Pshidatok, M.R. (2012). Bezopasnost lichnosti v kontekste transformatsii pravootnoshenii rossiiskogo obshchestva [Personal security in the context of the transformation of legal relations of Russian society], PhD diss. Krasnodar, 163 p.

Pudakov, E.R. (2017). Kriminologiia korruptsii v gosudarstvennoi sluzhbe [Criminology of corruption in the public service]. Moscow, Iurlitinform, $163 \mathrm{p}$.

Pugin, V.B. (2003). Sotsialnaia bezopasnost lichnosti: regionalnyi aspekt [Social security of the individual: a regional aspect], $\mathrm{PhD}$ diss. Arkhangelsk, $144 \mathrm{p}$.

Rossinskaia, E.R., Galiashin, E.I. (2012). O kompleksnoi prirode antikorruptsionnoi ekspertizy normativnykh pravovykh aktov $\mathrm{i}$ ikh proektov [On the complex nature of the anti-corruption expertise of regulatory legal acts and their projects], In Lex russica, 71 (5), 1048-1063.

Rudenko, S.I. (2010). Obespechenie prodovolstvennoi bezopasnosti Rossiiskoi Federatsii: teoriia, metodologiia, praktika [Ensuring food security of the Russian Federation: theory, methodology, practice]. Moscow, Dashkov i K०, 368 p. 
Rumiantsev, M.B. (2011). Klassifikatsiia istochnikov povyshennoi opasnosti po zakonodatelstvu Rossiiskoi Federatsii [Classification of sources of increased danger according to the legislation of the Russian Federation], In Sovremennoe parvo [Modern law], 5, 15-20.

Rybalkin, D.A. (2015). Formirovanie antikorruptsionnoi pozitsii kursantov vuzov MVD Rossii sredstvami sotsialno-kulturnoi deiatelnosti [Formation of the anti-corruption position of cadets of universities of the Ministry of Internal Affairs of Russia by means of socio-cultural activities], PhD diss. Kazan, $194 \mathrm{p}$.

Rybalkin, N.N. (2003). Priroda bezopasnosti [The nature of security], Dr. Sci. diss. Moscow, 407 p.

Sakharov, S.A. (2013). Sistema gosudarstvennoi vlasti i problema korruptsii v Pozdnei Rimskoi imperii: po dannym «Kodeksa Feodosiia» [The system of state power and the problem of corruption in the Late Roman Empire: according to the «Code of Theodosius»], PhD diss. Smolensk, 234 p.

Sergeeva, Iu.S. (2018). Formirovanie u studentov - budushchikh bakalavrov iurisprudentsii kompetentnosti $\mathrm{v}$ sfere protivodeistviia korruptsii [Formation of competence in the field of anti-corruption among students - future bachelors of jurisprudence], PhD diss. Moscow, $220 \mathrm{p}$.

Sevriugin, K.V. (2011). Protivodeistvie korruptsii v sisteme gosudarstvennoi grazhdanskoi sluzhby Rossiiskoi Federatsii: administrativno-pravovoe issledovanie [Anti-corruption in the system of the state civil service of the Russian Federation: administrative and legal research], PhD diss. Tyumen, $200 \mathrm{p}$.

Sharapova, E.A. (2017). Formirovanie antikorruptsionnoi napravlennosti lichnosti v professionalnom vospitanii studenta vuza [Formation of the anti-corruption orientation of the individual in the professional education of a university student], $\mathrm{PhD}$ diss. Krasnodar, $180 \mathrm{p}$.

Shchedrin, N.V. (2001). Mery bezopasnosti kak sredstvo preduprezhdeniia prestupnosti [Security measures as a means of crime prevention], Dr. Sci. diss. Krasnoyarsk, 348 p.

Shchedrin, N.V. (2008). Istochnik povyshennoi opasnosti, obieekt povyshennoi okhrany i mery bezopasnosti [Source of increased danger, object of increased security and security measures], In Gosudarstvo i parvo [State and law], 7, 16-24.

Shchedrin, N.V. (2014). O korruptsii, korruptsionerakh i korruptsionnoi vygode [About corruption, corrupt officials and corruption benefits], In NB: Voprosy prava i politiki [NB: Questions of law and politics], 3, 12-27. DOI: 10.7256/2305-9699.2014.3.10983.

Shchedrin, N.V. et al. (2010). Kontseptualno-teoreticheskie osnovy pravovogo regulirovaniia i primeneniia mer bezopasnosti [Conceptual and theoretical foundations of legal regulation and application of security measures]. Krasnoyarsk, SFU, 324 p.

Shchedrin, N.V., Damm, I.A. et al. (2020). Antikorruptsionnye mery bezopasnosti [Anti-corruption security measures]. Moscow, Prospekt, 496 p. DOI: 10.31085/9785392336746-2020-496.

Shcherbinin, P.V. (2003). Rol neitralnykh gosudarstv v formirovanii sistemy evropeiskoi bezopasnosti [The role of neutral states in the formation of the European security system], PhD diss. Moscow, 2003. $165 \mathrm{p}$.

Shedii, M.V. (2014). Korruptsiia kak sotsialnoe iavlenie: sotsiologicheskii analiz [Corruption as a social phenomenon: a sociological analysis], Dr. Sci. diss. Moscow, 393 p.

Sheverdiaev, S.N. (2020). Zakreplenie antikorruptsionnoi problematiki v sovremennom rossiiskom konstitutsionnom prave [Consolidation of anti-corruption issues in modern Russian constitutional law], Dr. Sci. diss. Moscow, $417 \mathrm{p}$.

Shishkarev, S.N. (2006). Pravovoi poriadok v sfere protivodeistviia korruptsii: teoretiko-pravovoe issledovanie [Legal order in the field of anti-corruption: theoretical and legal research], Dr. Sci. diss. Nizhny Novgorod, 2006. 228 p.

Siuzeva, N.V. (2016). Antikorruptsionnaia subkultura obrazovatelnoi organizatsii [Anti-corruption subculture of an educational organization], PhD diss. Ekaterinburg, $182 \mathrm{p}$.

Skliarov, S.V. (2015). Sootnoshenie poniatii korruptsionnogo prestupleniia i prestupleniia korruptsionnoi napravlennosti [Correlation of the concepts of a corruption crime and a corruption-related crime], In Vestnik Akademii Generalnoi prokuratury Rossiiskoi Federatsii [Herald of the Academy of the General Prosecutor's Office of the Russian Federation], 6, 35-37.

Solomin, S.K., Solomina, N.G. (2014). K voprosu o poniatii istochnika povyshennoi opasnosti [On the question of the concept of a source of increased danger], In Zakon [Law], 12, 82-89. 
Solovev, A.N. (2020). Soderzhanie i metodika formirovaniia kompetentsii po protivodeistviiu korruptsii u kursantov i slushatelei obrazovatelnykh organizatsii vysshego obrazovaniia Ministerstva oborony Rossiiskoi Federatsii [The content and methodology of the formation of competencies for combating corruption among cadets and students of educational organizations of higher education of the Ministry of Defense of the Russian Federation], PhD diss. Saint Petersburg, 205 p.

Sorochkin, R.A. (2020). Poniatie i priznaki korruptsionnogo prestupleniia [The concept and signs of a corruption crime], In Gosudarstvo i parvo [State and law], 5, 147-152. DOI: 10.31857/S013207690009689-9.

Spektor, E.I. (2015). Korruptsionnye pravonarusheniia: problemnye voprosy iuridicheskoi kvalifikatsii [Corruption offenses: problematic issues of legal qualification], In Zhurnal rossiiskogo prava [Journal of Russian Law], 19 (8), 40-46. DOI: 10.12737/12226.

Storchilova, N.V. (2017). Osobennosti lichnosti korruptsionnogo prestupnika [Features of the personality of a corrupt criminal], In Vestnik Vserossiiskogo instituta povysheniia kvalifikatsii sotrudnikov Ministerstva vnutrennikh del Rossiiskoi Federatsii [Herald of the All-Russian Institute for Advanced Training of Employees of the Ministry of Internal Affairs of the Russian Federation], 42 (2), 32-37.

Sukhanov, V.A. (2015). Mezhdunarodnoe sotrudnichestvo v borbe s korruptsiei v organakh vlasti [International cooperation in the fight against corruption in government bodies], $\mathrm{PhD}$ diss. Moscow, $186 \mathrm{p}$.

Sundukova, V.V. (2020). Lichnostnye determinanty antikorruptsionnoi napravlennosti kursantov obrazovatelnykh organizatsii FSIN Rossii [Personal determinants of anti-corruption orientation of cadets of educational organizations of the Federal Penitentiary Service of Russia], PhD diss. Moscow, $185 \mathrm{p}$.

Surkov, K.V. (2013a). Antikorruptsionnoe parvo: uchebnik v 3 tomakh. T. 1: Poniatie i predmet. Istochniki. Stanovlenie i razvitie antikorruptsionnogo zakonodatelstva. Organizatsiia upravleniia antikorruptsionnoi deiatelnosti [Anti-corruption law: textbook in 3 volumes. Vol. 1: Concept and subject. Sources. Formation and development of anti-corruption legislation. Organization of the management of anti-corruption activities]. Chita, RIK ZabGU, 419 p.

Surkov, K.V. (2013b). Antikorruptsionnoe parvo: uchebnik v 3 tomakh. T. 2: Korruptsionnaia otvetstvennost [Anti-corruption law: textbook in 3 volumes. Vol. 2: Corruption responsibility]. Chita, RIK ZabGU, $559 \mathrm{p}$.

Surkov, K.V. (2014). Antikorruptsionnoe parvo: uchebnik v 3 tomakh. T. 3: Dosudebnoe proizvodstvo po ugolovnym delam o korruptsionnykh prestupleniiakh [Anti-corruption law: textbook in 3 volumes. Vol. 3: Pre-trial proceedings in criminal cases of corruption crimes]. Chita, RIK ZabGU, 623 p.

Talapina, E.V. (2007). Ob antikorruptsionnoi ekspertize [About anti-corruption expertise], In Zhurnal rossiiskogo prava [Journal of Russian Law], 11 (5,) 52-66.

Tereshchenko, I.A. (2010). Korruptsiia kak faktor ugrozy natsionalnoi bezopasnosti Rossiiskoi Federatsii (politologicheskii analiz) [Corruption as a threat factor to the national security of the Russian Federation (political science analysis)], $\mathrm{PhD}$ diss. Moscow, 2010. $226 \mathrm{p}$.

Tokarev, B.B. (2011). Sotsialno-filosofskoe osmyslenie fenomena korruptsii [Socio-philosophical understanding of the phenomenon of corruption], PhD diss. Moscow, $193 \mathrm{p}$.

Trunov, I.L. (2014). Neobkhodimost reformy advokatury Rossii [The need for reform of the Russian bar], In Rossiiskii zhurnal pravovykh issledovanii [Russian Journal of Legal Research], 4, 41-45.

Trushkina, N.V. (2018). Korruptsionnye faktory v sfere notariata [Corruption factors in the notarial sphere], In Finansovaia ekonomika [Financial economics], 6, 1229-1231.

Tsirin, A.M. (2016). Preduprezhdenie korruptsii: problemy i perspektivy [Prevention of corruption: problems and prospects], In Zhurnal rossiiskogo prava [Journal of Russian Law], 20 (12), 106-115. DOI: $10.12737 / 22727$.

Tsirin, A.M., Truntsevskii, Iu.V., Sevalnev, V.V. (2019). Otsenka korruptsionnykh riskov v federalnykh organakh ispolnitelnoi vlasti [Assessment of corruption risks in federal executive authorities]. Moscow, Prospekt, 112 p. DOI: 10.31085/9785392288076-2019-112.

Ulianovskii, M.P. (2006). Institutsionalnaia transformatsiia rossiiskogo obshchestva: aspekt sotsialnoi bezopasnosti [Institutional transformation of Russian society: the aspect of social security], $\mathrm{PhD}$ diss. Krasnodar, 151 p. 
Ursul, A.D. (2014). Problemy bezopasnosti i ustoichivogo razvitiia: evoliutsionnyi podkhod i mezhdistsiplinarnye perspektivy [Problems of security and sustainable development: an evolutionary approach and interdisciplinary perspectives], In Voprosy bezopasnosti [Security issues], 5, 1-62. DOI: 10.7256/24097543.2014.5.14221.

Useev, R.Z. (2017). Obespechenie bezopasnosti ugolovno-ispolnitelnoi sistemy: teoretiko-pravovye i organizatsionnye aspekty [Ensuring the security of the penal enforcement system: theoretical, legal and organizational aspects]. Samara, $220 \mathrm{p}$.

Varnavskii, V.V. (2003). Vneshneekonomicheskaia bezopasnost i inostrannye investitsii v Rossii [Foreign economic security and foreign investments in Russia], PhD diss. Moscow, $160 \mathrm{p}$.

Vorontsov, S.A. (2015a). Ob organizatsii antikorruptsionnogo prosveshcheniia v Rossiiskoi Federatsii [About the organization of anti-corruption enlightenment in the Russian Federation], In Severo-Kavkazskii iuridicheskii vestnik [North-Caucasian Legal Bulletin], 1, 105-111.

Vorontsov, S.A. (2015b). Protivodeistvie korruptsii: teoriia i praktika [Anti-corruption: theory and practice], In Severo-Kavkazskii iuridicheskii vestnik [North-Caucasian Legal Bulletin], 3, 51-59.

Vozzhenikov, A.V. (2002). Natsionalnaia bezopasnost $\mathrm{v}$ kontekste sovremennogo politicheskogo protsessa Rossii: teoriia i politika obespecheniia [National security in the context of the modern political process of Russia: theory and policy of ensuring], Dr. Sci. diss. Moscow, 391 p.

Zagashvili, V.S. (1997). Ekonomicheskaia bezopasnost Rossii [Economic security of Russia]. Moscow, Iuristie, $238 \mathrm{p}$.

Zentsova, S.A. (2011). Istochnik povyshennoi opasnosti i ego ugolovno-pravovoe znachenie [The source of increased danger and its criminal and legal significance]. Saint Petersburg, Iuridicheskii tsentr Press, $224 \mathrm{p}$.

Zhubrin, R.V. et al. (2017). Lichnost korruptsionnogo prestupnika [The personality of a corrupt criminal]. Moscow, Prospekt, 384 p. DOI: 10.31085/9785392292400-2019-384.

Zhubrin, R.V., Ilii, S.K. (2017). Problemy vozmeshcheniia ushcherba ot korruptsionnykh prestuplenii i pravonarushenii [Problems of compensation for damage from corruption crimes and offenses], In Vestnik Akademii Generalnoi prokuratury Rossiiskoi Federatsii [Herald of the Academy of the General Prosecutor's Office of the Russian Federation], 3, 70-77.

Zyrianova, I.A. (2014). Problema opredeleniia poniatiia i perechnia korruptsionnykh pravonarushenii [The problem of defining the concept and list of corruption offenses], In Vestnik Vladimirskogo iuridicheskogo instituta [Herald of the Vladimir Law Institute], 2, 105-108. 